\title{
Sugarcane yields, juice quality and stem borer (Eldana saccharina W) infestations as influenced by increasing nitrogen rates in Ferké, Northern Ivory Coast
}

\author{
Crépin B. Péné ${ }^{*}$ Yah Coulibaly-Ouattara
}

SUCAF-CI/SOMDIAA, Research and Development Department, 22 rue des Corrossiers, Zone 3 Abidjan-Treichville, 01 BP1967 Abidjan 01, Ivory Coast.

${ }^{*}$ Corresponding author. E-mail: bpene@sucafci.somdiaa.com.

Accepted $29^{\text {th }}$ April, 2019.

\begin{abstract}
Sugarcane is an important cash crop in Ivory Coast with a total production of about 2 million tons of cane/annum and 200,000 tons of sugar/annum. It contributes to about $1.2 \%$ of total country DGP and $3.3 \%$ of agricultural GDP. However, stem borer (Eldana saccharina W) infestations in Ferké sugarcane plantations have significantly impacted both cane and sugar yields over the last three cropping seasons with total sugar losses estimated to 5,000 tons in 2016-17. That pest damage outbreak was hypothesized to be linked to higher fertilizer rates applied to sugarcane plantations over 2014-15 and 2015-16 cropping seasons. The study aimed to determine the optimum Nfertilizer rate in sugarcane that could maintain stem borer infestations under control (BIN $\leq 5 \%$ ). It was carried out on a commercial plantation of Ferké 2 sugar mill in northern Ivory Coast. That field which was cultivated with SP70-1006 variety was sprinkler irrigated with a center pivot and the experimental design was a randomized complete block with 11 $\mathrm{N}$-fertilizer rates in four replications. Results obtained over two successive cropping seasons showed that, in plant cane, yield performance, cane juice quality and stem borer infestations were not significantly influenced by fertilizer treatments indicating that nitrogen was not a limiting factor in the soil profile to crop growth and development probably due to the decay of organic matter as a result of soil tillage. In contrast, in first ratoon, cane yields and stem borer infestations in terms of per cent of bored cane and bored internode percentage were significantly influenced by $\mathrm{N}$-fertilizer treatments with an optimum rate of 100 to $110 \mathrm{~kg} \mathrm{~N} / \mathrm{ha}$. Cane yield increase resulting from additional $\mathrm{N}$-fertilizer applications to that optimum rate was very little compared to the return cost of fertilizer with higher levels of stem borer infestations $(>8 \%$ BIN).
\end{abstract}

Keywords: Farming practice, denitrification, microbial immobilization, environmental impact, natural enemy, integrated management.

\section{INTRODUCTION}

Sugarcane is considered as the most suitable tropical crop for biofuel production, but surprisingly high nitrogen fertilizer applications in main sugar producing countries raise doubt about the sustainability of production and are at odds with a carbon-based cropping system (Robinson et al., 2011).
Total land surface under sugarcane cultivation in Ivory Coast is about 30,000 ha with 23,000 ha of industrial plantations managed by two private companies $(77 \%)$ and 7,000 ha of rainfed village plantations $(23 \%)$ owned by families or cooperatives (Péné et al., 2019). Village plantations are located in the surroundings of industrial 
plantations to limit cane juice quality degradation before milling and cane transportation costs after harvest.

Industrial plantations are mainly under sprinkler irrigation $(85 \%)$, the remaining being rainfed $(15 \%)$ with 19,550 and 3,450 ha, respectively. Total sugarcane and cane sugar productions of the country are about 2 million $t$ and 200,000 t per annum respectively. These productions are achieved on four sugar estates (or sugar mill plantations), namely Ferké 1, Ferké 2, Borotou-Koro and Zuénoula of approximately 7,500 ha each located in central and northern Ivory Coast. Sugar production represents about $1.2 \%$ of country total GDP and $3.3 \%$ of agricultural GDP, with around 20,000 direct and indirect jobs provided by the sugar sector.

Prior to heavy borer damage observed at harvest in Ferké 1 sugar estate over 2015-16 cropping season with on average $6.7 \% \mathrm{BIN}$, the pest incidence although maintained below the tolerable threshold ( $5 \%$ BIN) was much more endemic in Ferké 1 with on average 2.6 to $4.5 \%$ BIN compared to 0.9 to $2 \%$ in Ferké 2 (Péné et al., 2018). In Ferké 2, the threshold was outreached in 201617 with $5.6 \%$ BIN on average. Higher values were reached in 2016-17 in both sugar estates with on average 7.6 and $5.6 \%$ in Ferké 1 and Ferké 2, respectively. A significant reduction of one point in Ferké 1 compared to 0.2 point in Ferké 2 occurred over 2017-18 cropping season. This was partly due to limitations in nitrogen fertilizer rates implemented in $2016-17$ by $25-30 \%$, i.e. on average $115 \mathrm{~kg} \mathrm{~N} / \mathrm{ha}$ under irrigation instead of $160 \mathrm{~kg} / \mathrm{ha}$ or even $250 \mathrm{~kg} / \mathrm{ha}$ applied over 2014-15 and 2015-16 cropping seasons (Péné et al., 2018).

In most sugarcane growing regions worldwide, stem borers are economically important pests as they significantly reduce yields of number of food crops such as rice, sorghum, corn and sugarcane (Polaszek, 1998; Goebel and Nikpay, 2017). Several species of lepidopteran borers causing such damage levels belong to genus Chilo, Sesamia, Diatraea and Eldana. The African stem borer E. saccharina Walker (Lepidoptara: Pyralidae) is known as the main insect pest in sugarcane which larva cause galleries into cane stalks (Dick, 1945; Leslie, 2009), especially on their lower parts (Mazodze and Conlong, 2003). This damage on stem tissues being afterwards infected by fungi species (Fusarium spp.) are characterized by a dark-red coloring of surrounding tissues of galleries (McFarlane et al., 2009). Eldana Saccharina's damage affects young and adult cane stalks (as opposed to that of other stem borer species like Sesamia calamistis, Chilo partellus and C. sacchariphagus on young tillers) increase with crop age, especially over 12 to 16 months of vegetation (Leslie, 2009). Number of research works carried out over the last 25 years focused on biological control and varietal resistance regarding two major stem borer species, namely $E$. saccharina and $C$. sacchariphagus. If varietal resistance became more successful, it was not the case of biological control which is more difficult to implement, especially on E. saccharina (Conlong, 1994). The importance of some farming practices such as nitrogen and silicon fertilizer applications in the control of stem borer populations was reported by several authors (Paxton, 1982; Way et al., 2003; Lopez et al., 1983; Goebel et al., 2005; Kvedaras et al., 2007; Kouamé et al., 2010; Nikpay et al., 2015; Péné et al., 2016).

The study aimed to determine the optimum $\mathrm{N}$-fertilizer rate in sugarcane that could maintain stem borer infestations under control ( $5 \%$ bored internodes).

\section{MATERIALS AND METHODS}

\section{Study site}

The study was carried out on Ferké 2 sugarcane field P7100 sprinkler irrigated with center pivot, in northern Ivory Coast $\left(9^{\circ} 20^{\prime}\right.$ to $9^{\circ} 60^{\prime} \mathrm{N}, 5^{\circ} 22^{\prime}$ to $\left.5^{\circ} 40^{\prime} \mathrm{O}, 325 \mathrm{~m}\right)$. The prevailing climate is tropical dry with two seasons: one, starting from November to April, is dry and the other, from May to October, is wet. The rainfall pattern is unimodal and centered on August and September which total amount of rainfall reaches almost half of the average annual rainfall $(1200 \mathrm{~mm})$ with an average daily temperature of $27^{\circ} \mathrm{C}$. To meet sugarcane crop water requirements, the total amount of irrigation water required reaches $700 \mathrm{~mm} /$ year (Konan et al., 2017a; Konan et al., 2017b; Péné et al., 2012). Main soil textures are ferralsols as defined by the FAO (2015) in accordance with the USDA Soil Taxonomy (1999) and temporally waterlogged soils in valley bottoms of Bandama and Lokpoho river basins with a sandy-clay texture.

\section{Experimental design}

The experiment was laid out following a randomized complete block design with $11 \mathrm{~N}$-fertilizer rates applied once every crop cycle $(0,20,40,60,80,100,120,140$, $160,180,200 \mathrm{~kg} / \mathrm{ha}$ ) in four replicates. Nitrogen was supplied through NPK mineral fertilizer composed of $16 \% \mathrm{~N}, 8.5 \% \mathrm{P}_{2} \mathrm{O}_{5}$ and $23 \% \mathrm{~K}_{2} \mathrm{O}$. Each experimental plot comprised five double rows of $5 \mathrm{~m}$ with 0.5 and $1.90 \mathrm{~m}$ inter-row spacing which gives a total surface of $47.5 \mathrm{~m}^{2}$. Only three central cane rows were weighed at harvest per plot, that is, a net surface of $28.5 \mathrm{~m}^{2}$.

\section{Cropping conditions}

The cane variety cultivated was SP70-1006 used in experiment as plant cane and first ratoon. The crop was planted manually on March 21, 2017 and harvested manually twice after burning on February 10, 2018 and February 23, 2019. A part from fertilization, other cropping operations like soil tillage, planting, pre- 


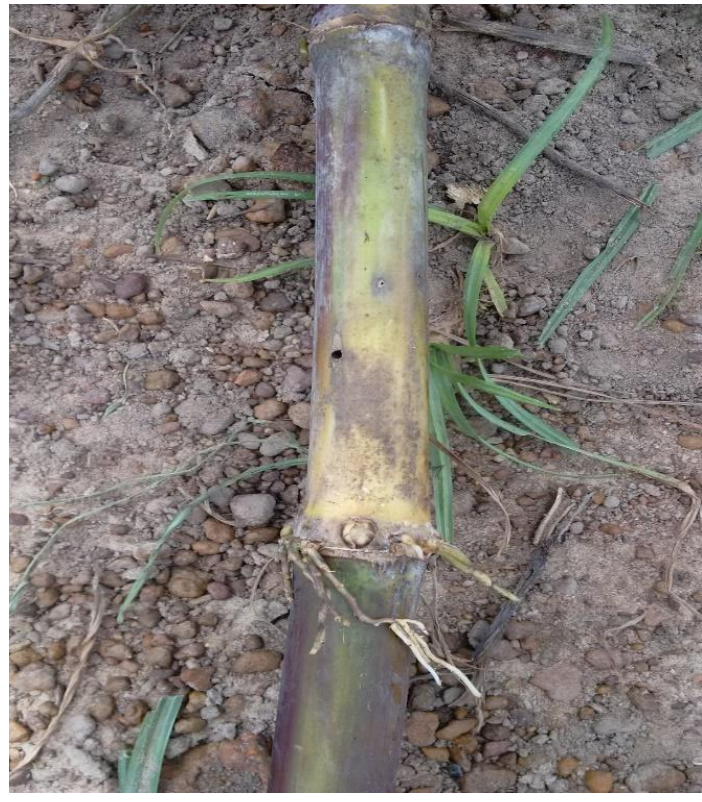

A: cane stalk bored

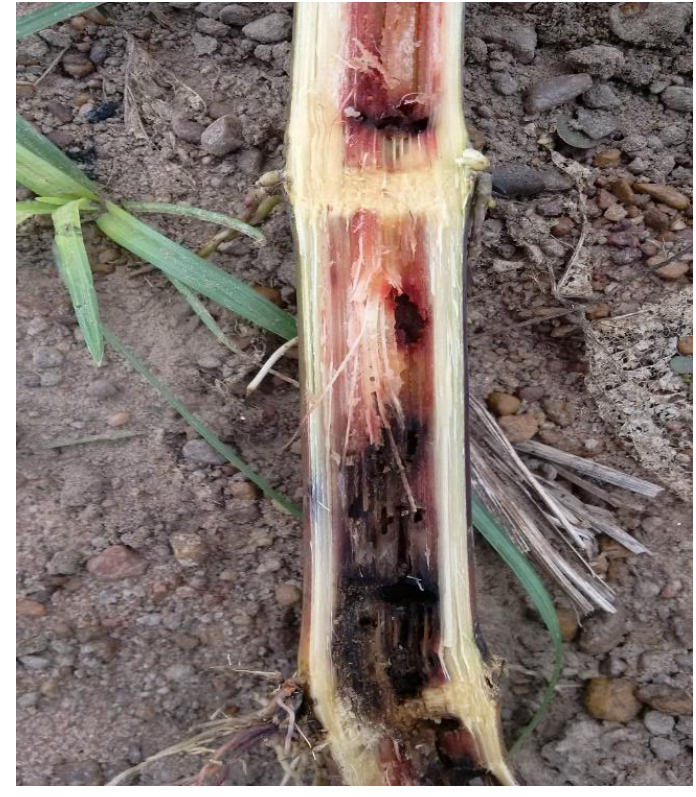

B: Cane stalk splitted longitudinally

Figure 1. Stem borer E. saccharina damage on an adult cane stalk in Ferké, Ivory Coast.

emergence herbicide application (pendimethalin + chlorimuron-ethyl + metribuzine), sprinkler irrigation and manual harvesting were conducted homogenously on all treatments following standard recommendations in sugarcane.

\section{Field observations made during vegetation and at harvest}

Over the growing stage, that is, from the age of 2 to 8 months, crop height measurements were made every two weeks on 10 randomly selected cane stalks per plot. At harvest, burned cane fresh production of 3 central double rows of each plot was weighed separately to determine crop yield. Moreover, 50 millable whole stalks were randomly chosen within each plot and splitted longitudinally with a machete in order to determine the percentage of bored or damaged internode and cane (\%BIN, \%BC) by stem borer (Figure 1).

\section{Sucrose analyses at harvest}

At harvest, 30 millable whole cane stalks were sampled randomly per plot for sucrose analysis in the laboratory. Prior to sample grinding operations in the laboratory for sucrose analyses, each stalk was cut into 3 pieces of almost equal length while separating them in basal, median and top parts. This procedure allowed to randomly reconstitute three batches of 10 stalks for a better homogenization of the initial field sample by permutation of the pieces so that each reconstituted stalk was composed of parts coming from 3 different cane stalks. Eventually, only one batch of 10 reconstituted stalks ( $1 / 3$ of initial sample) were ground for a series of sucrose analyses to determine the sucrose content $(\mathrm{Pol} \% \mathrm{C})$, fiber content (Fiber \%C), juice purity (Purity $\% \mathrm{C})$ and recoverable sucrose $(\mathrm{SE} \% \mathrm{C})$. Equipment used comprised a Jefco cutter grinder, a hydraulic press Pinette Emideceau, a digital refractometer BS-RFM742 and a digital polari-meter SH-M100. Methods used in the determination of required technological parameters were reported by Hoarau (1970). The recoverable sucrose was calculated as follows (Péné et al., 2016; Hugot, 1999).

SE \%C $=[(0.84 \times$ Pol\%C $)(1.6-60 /$ Purity $)-(0.05 \times$ Fib $\% \mathrm{C})]$ with:

Purity $\% \mathrm{C}=($ Pol juice $/$ Brix $) \times 100$ and Pol juice $=$ Pol factor $\times$ Pol read.

Pol\% $\%$ = Factor $\mathrm{n} \times$ Pol juice

Factor pol depending on brix value (amount of soluble dry matter in juice measured with a refractometer) is provided by Schmidt table relative to a polarimeter for $26 \mathrm{~g}$ of glucose. The fiber content and factor $n$ were provided by a table depending on the weight of fiber cake obtained after pressing $500 \mathrm{~g}$ of cane pulp resulting from the grinding operation of every sample of cane stalks.

\section{Statistical analyses}

Not only cane and sugar yields but also juice quality 
Table 1. Physical and chemical soil properties of land surface used for experiment prior to planting (0 - $30 \mathrm{~cm}$ horizon).

\begin{tabular}{lcllc}
\hline Physical soil properties & & & Chemical soil properties & \\
\cline { 1 - 2 } \cline { 5 - 6 } Criteria & Values & & Criteria & Values \\
\hline Depth $(\mathrm{m})$ & 0.80 & & $\mathrm{pH}$ & 6.1 \\
MC at pF2.5 $(\%)$ & 20.8 & & OM $(\%)$ & 1.6 \\
MC at pF4.2 $(\%)$ & 8.5 & & Total N $(\%)$ & 0.06 \\
Clay $(\%)$ & 20.0 & & C $/ \mathrm{N}(-)$ & 14 \\
Sand $(\%)$ & 64.3 & & Base saturation ratio $(\%)$ & 13.7 \\
Silt $(\%)$ & 15.7 & & Sum of bases $(\mathrm{meq} / 100 \mathrm{~g})$ & 2.1 \\
AM $(\mathrm{m})$ & 1.10 & & CEC $(\mathrm{meq} / 100 \mathrm{~g})$ & 16.7 \\
\hline
\end{tabular}

MC: moisture content; AM: available moisture; OM: organic matter; CEC cation exchange capacity; Texture: sandy-clay.

Table 2. Plant crop cane quality, yields and stem borer infestations in response to increasing $\mathrm{N}$ rates in Ferké, Ivory Coast.

\begin{tabular}{|c|c|c|c|c|c|c|c|c|}
\hline \multirow[b]{2}{*}{$\begin{array}{l}\text { Nitrogen } \\
\text { rates }\end{array}$} & \multicolumn{4}{|c|}{ Cane quality criteria } & \multicolumn{2}{|c|}{ Yields (t/ha) } & \multirow[b]{2}{*}{ BIN (\%) } & \multirow[b]{2}{*}{$\begin{array}{c}\text { NMS } \\
(\times 1000 / h a)\end{array}$} \\
\hline & Purity (\%) & $\begin{array}{c}\text { Sucrose } \\
(\%)\end{array}$ & Fiber (\%) & $\begin{array}{l}\text { Recoverable } \\
\text { sucrose (\%) }\end{array}$ & Cane & Sugar & & \\
\hline No & 87.8 & 13.7 & 13.8 & 9.9 & 106.8 & 10.6 & 14.0 & 96.7 \\
\hline N20 & 87.7 & 13.4 & 13.6 & 9.6 & 99.4 & 9.5 & 15.2 & 90.2 \\
\hline N40 & 88.9 & 14.5 & 13.4 & 10.6 & 101.7 & 10.8 & 16.5 & 95.5 \\
\hline N60 & 86.4 & 12.9 & 13.6 & 9.1 & 104.6 & 9.5 & 16.0 & 93.5 \\
\hline N80 & 88.1 & 13.8 & 14.1 & 9.9 & 98.8 & 9.8 & 16.0 & 97.2 \\
\hline N100 & 86.8 & 12.9 & 13.7 & 9.2 & 102.4 & 9.3 & 14.9 & 92.2 \\
\hline N120 & 87.5 & 13.6 & 13.8 & 9.8 & 98.6 & 9.6 & 16.7 & 92.5 \\
\hline N140 & 87.3 & 13.3 & 13.9 & 9.5 & 101.2 & 9.6 & 16.7 & 91.5 \\
\hline N160 & 86.5 & 12.9 & 14.5 & 9.1 & 100.1 & 9.1 & 16.6 & 97.5 \\
\hline N180 & 87.8 & 13.5 & 14.2 & 9.7 & 96.7 & 9.4 & 17.4 & 95.2 \\
\hline N200 & 87.9 & 13.5 & 14.0 & 9.7 & 105.6 & 10.3 & 17.5 & 99.5 \\
\hline Mean & $87.5 \pm 0.2$ & $13.4 \pm 0.1$ & $13.9 \pm 0.1$ & $9.6 \pm 0.1$ & $101.4 \pm 0.9$ & $9.8 \pm 0.1$ & $16.1 \pm 0.3$ & $94.7 \pm 0.9$ \\
\hline CV (\%) & 1.5 & 5.2 & 3.3 & 6.7 & 6.1 & 8.5 & 12.1 & 6.6 \\
\hline SD & 1.3 & 0.7 & 0.5 & 0.6 & 6.2 & 0.8 & 2.0 & 6.3 \\
\hline Block effect. & $0.67 \mathrm{~ns}$ & $0.56 \mathrm{~ns}$ & $0.003^{* *}$ & $0.52 \mathrm{~ns}$ & $0.78 \mathrm{~ns}$ & 0.52 ns & $0.00^{* *}$ & $0.00^{* *}$ \\
\hline $\mathrm{N}$-fertilize & $0.30 \mathrm{~ns}$ & $0.09 \mathrm{~ns}$ & $0.060 \mathrm{~ns}$ & $0.09 \mathrm{~ns}$ & $0.43 \mathrm{~ns}$ & $0.15 \mathrm{~ns}$ & $0.33 \mathrm{~ns}$ & $0.58 \mathrm{~ns}$ \\
\hline
\end{tabular}

BIN: bored internode by $E$. saccharina; NMS: number of millable stalks/ha; $\mathrm{SE}_{\text {mean }}=\mathrm{SD}_{\text {mean }} / \sqrt{ } \mathrm{n}$

parameters and stem borer infestations were analyzed statistically to look at whether differences observed among each set of data following $\mathrm{N}$-fertilizer treatments were significant or not. The statistical software used was STATISCA 8.0 and the Duncan Test was used to determine the differences between means of treatments.

\section{RESULTS}

\section{Soil characteristics prior to planting}

Soil prior to planting was poor in organic matter and total nitrogen with a high $\mathrm{C} / \mathrm{N}$ ratio (>12) suggesting a slow mineralization process of organic matter (Table 1). Soil reaction, moderately acidic $(\mathrm{pH} \mathrm{6.1)}$, and average depth of $0.80 \mathrm{~m}$ were good enough for sugarcane cultivation. Soil texture was sandy-clay with high available moisture $(110 \mathrm{~mm})$, i.e. about $70 \mathrm{~mm}$ of readily available moisture.

\section{Plant cane yields and stem borer infestations}

No significant difference between $\mathrm{N}$-fertilizer rates was observed with respect to each agronomic parameter, particularly cane and sugar yields as well as stem borer infestations (Table 2). This shows that soil $\mathrm{N}$ was not a limiting factor even for the zero fertilizer rate, as it derived from the mineralization process of organic matter like previous cane stools enhanced in plant cane as a result of soil tillage. This finding suggests that $\mathrm{N}$-fertilization in plant cane might be limited to reduce production cost, 


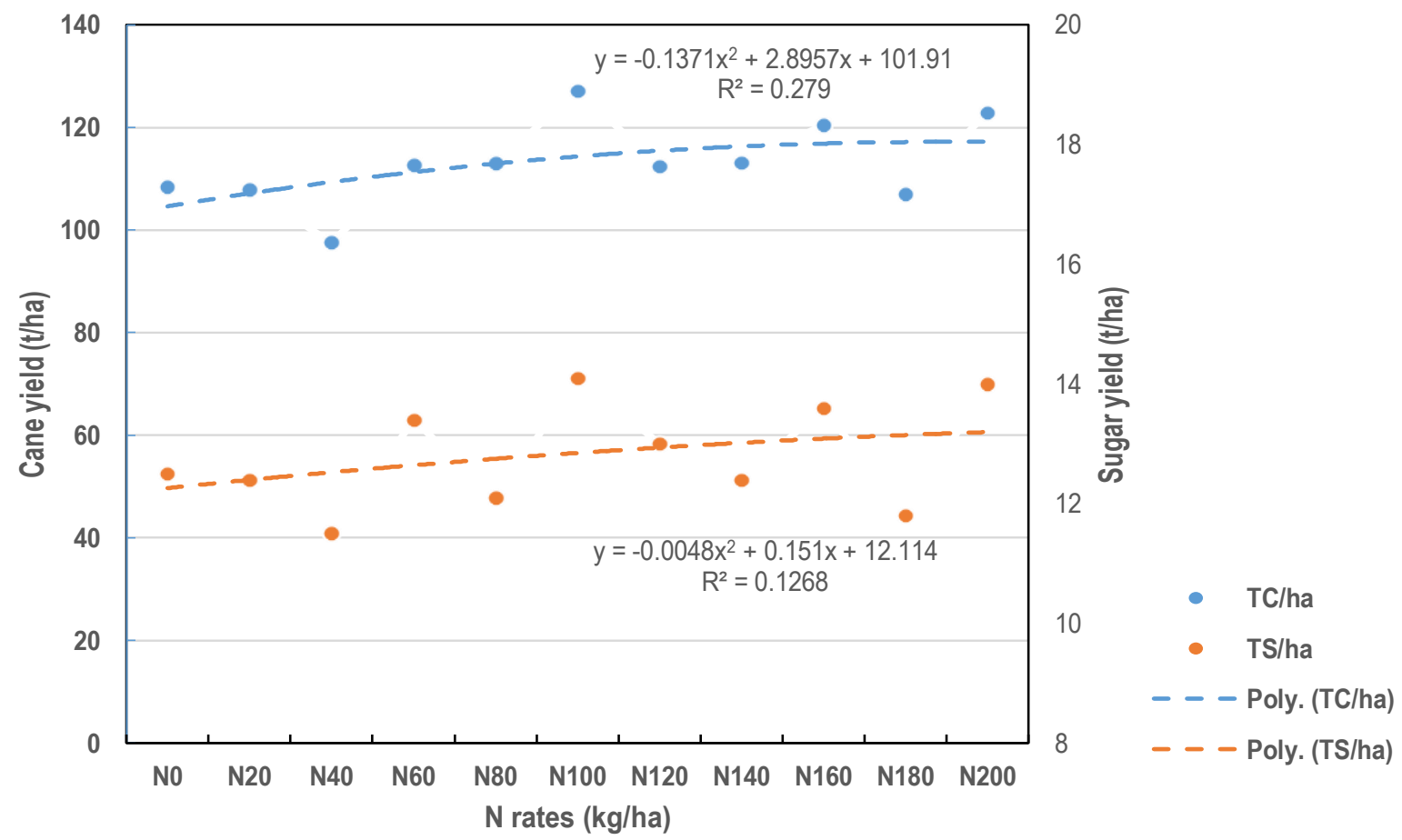

Figure 2. Cane and sugar yield response of first ratoon crop to increasing $\mathrm{N}$ rates In Ferké, Northern Ivory Coast.

improve cane maturity and prevent stem borer infestations.

\section{First ratoon crop cane yields and stem borer infestations}

Significant differences in cane yields were obtained between $\mathrm{N}$ rates in first ratoon. Nevertheless, cane yield increase obtained over $\mathrm{N}$ rate of 100 to $110 \mathrm{~kg} / \mathrm{ha}$ was low i.e. less than 5 t/ha as compared to the cost of supplementary $\mathrm{N}$ applied. In contrast, no significant difference in sugar yields was observed between $\mathrm{N}$ rates applied in first ratoon. This means that in ratoon sugarcane, at $\mathrm{N}$-rates higher than 100 to $110 \mathrm{~kg} / \mathrm{ha}$, sugar yield increase is negligible. That is not the case for the return cost of any additional $\mathrm{N}$-rate applied.

In both cases, not only the additional $\mathrm{N}$ applied in ratoon to $100-110 \mathrm{~kg} / \mathrm{ha}$ was not compensated by the yield increase obtained but also crop may be subjected to high stem borer infestations. It will be shown later on that those infestations and the additional $\mathrm{N}$-rate were damaging to cane juice quality and therefore to sugar yield (Figure 2).

\section{Stem borer infestation response curves in first ratoon crop}

Significant differences in cane and internode bored percentage were observed within N-rates applied in first ratoon with severe infestations over $110 \mathrm{~kg} \mathrm{~N} / \mathrm{ha}$. Although infestations due to control zero $\mathrm{N}$ were higher than those of $40 \mathrm{~kg} / \mathrm{ha}(\mathrm{N} 40)$, both treatments were not significantly different with on the one hand 7.3 and $5.7 \%$ $\mathrm{BIN}$ and on the other hand 65 and $59 \% \mathrm{BC}$. This means that differences observed were due to experimental error regarding mostly soil heterogeneity (Table 3 ).

Because of imbalance between stem borer population and that of natural ennemies (parasitoids) being faced over the last three years on Ferké sugar mill plantations, it could be worthwhile to limit $\mathrm{N}$-fertilier rates for a moment. Moreover, it was shown that under sugarcane farming conditions of Ferké, crop yield increase resulting from a N-rate higher than 100 to $110 \mathrm{~kg} / \mathrm{ha}$ was not significant compared to the return cost of additional $\mathrm{N}$ rate (Figure 3 ). That is why total cane production loss observed over 2018-19 harvest season in Ferké sugar mill plantations (-40 $000 \mathrm{t}$ ) could not be explained by the decrease in $\mathrm{N}$-fertilizer rates being implemented since 2016-17. This is corroborated by higher cane and sugar production achieved in the following harvest season with 1035000 and $107800 \mathrm{t}$ obtained respectively in the context of limitation of $\mathrm{N}$-fertilizer rates to prevent high stem borer infestations. Moreover, despite very high $\mathrm{N}$ fertilizer rates applied to sugarcane plantations (up to 250 $\mathrm{kgN} / \mathrm{ha}$ ) over two subsequent cropping seasons (2014-15 and 2015-16), cane and sugar productions achieved in 2015-16 and 2016-17 were disappointing with, respectively, $934976 \mathrm{t}$ cane (93 $846 \mathrm{t}$ sugar) and $965440 \mathrm{t}$ cane 
Table 3. First ratoon crop cane quality, yields and stem borer infestations in response to increasing $\mathrm{N}$ rates in Ferké, Ivory Coast.

\begin{tabular}{|c|c|c|c|c|c|c|c|c|}
\hline \multirow{2}{*}{$\begin{array}{l}\text { Nitrogen } \\
\text { rates }\end{array}$} & \multicolumn{4}{|c|}{ Cane quality criteria } & \multicolumn{2}{|c|}{ Yields } & \multirow[b]{2}{*}{ INB (\%) } & \multirow{2}{*}{$\begin{array}{l}\text { NMS *1000 } \\
\text { (/ha) }\end{array}$} \\
\hline & Purity (\%) & $\begin{array}{c}\text { Sucrose } \\
(\%)\end{array}$ & $\begin{array}{c}\text { Fiber } \\
(\%)\end{array}$ & $\begin{array}{l}\text { Recoverable } \\
\text { sucrose (\%) }\end{array}$ & Cane (t/ha) & $\begin{array}{l}\text { Sugar } \\
\text { (t/ha) }\end{array}$ & & \\
\hline No & 90.4 & 15.4 & 14.3 & 11.4 & $108.4^{\mathrm{ab}}$ & 12.5 & $7.3^{\mathrm{ab}}$ & 89.7 \\
\hline N20 & 90.6 & 15.5 & 14.2 & 11.5 & $107.9^{\mathrm{ab}}$ & 12.4 & $7.3^{\mathrm{ab}}$ & 88.2 \\
\hline N40 & 90.6 & 15.8 & 13.6 & 11.8 & $97.6^{a}$ & 11.5 & $5.7^{\mathrm{a}}$ & 84.5 \\
\hline N60 & 90.6 & 15.9 & 13.3 & 11.9 & $112.7^{\mathrm{ab}}$ & 13.4 & $7.5^{\mathrm{ab}}$ & 76.2 \\
\hline N80 & 89.2 & 14.7 & 13.6 & 10.7 & $113.0^{\mathrm{ab}}$ & 12.1 & $9.9 b^{c}$ & 78.7 \\
\hline N100 & 89.6 & 15.0 & 14.0 & 11.1 & $127.2^{\mathrm{b}}$ & 14.1 & $10.6^{\mathrm{bc}}$ & 83.5 \\
\hline N120 & 90.7 & 15.5 & 13.6 & 11.6 & $112.5^{\mathrm{ab}}$ & 13.0 & $12.3^{\mathrm{c}}$ & 85.0 \\
\hline N140 & 89.4 & 14.9 & 13.1 & 11.0 & $113.2^{\mathrm{ab}}$ & 12.4 & $11.2^{\mathrm{bc}}$ & 79.5 \\
\hline N160 & 89.6 & 15.3 & 14.0 & 11.3 & $120.5^{\mathrm{ab}}$ & 13.6 & $12.2^{\mathrm{c}}$ & 85.5 \\
\hline N180 & 89.5 & 15.0 & 13.5 & 11.0 & $107.0^{\mathrm{ab}}$ & 11.8 & $10.3^{b c}$ & 87.0 \\
\hline N200 & 90.6 & 15.4 & 13.9 & 11.4 & $122.8^{\mathrm{ab}}$ & 14.0 & $11.9^{c}$ & 77.7 \\
\hline Mean & $90.1 \pm 0.2$ & $15.3 \pm 0.1$ & $13.7 \pm 0.1$ & $11.3 \pm 0.1$ & $113.0 \pm 1.6$ & $12.8 \pm 0.2$ & $9.6 \pm 0.3$ & $83.2 \pm 1.4$ \\
\hline CV (\%) & 1.2 & 4.5 & 4.4 & 5.5 & 9.6 & 11.4 & 19.6 & 11.0 \\
\hline SD & 1.1 & 0.7 & 0.6 & 0.6 & 10.9 & 1.5 & 1.9 & 9.2 \\
\hline $\begin{array}{l}\text { Block } \\
\text { effect. }\end{array}$ & $0.01^{* *}$ & $0.06 \mathrm{~ns}$ & $0.06 \mathrm{~ns}$ & 0.05 & $0.27 \mathrm{~ns}$ & $0.18 \mathrm{~ns}$ & $0.00^{\star \star}$ & $0.25 \mathrm{~ns}$ \\
\hline $\begin{array}{l}\mathrm{N}- \\
\text { fertilizer }\end{array}$ & $0.335 \mathrm{~ns}$ & $0.27 \mathrm{~ns}$ & $0.23 \mathrm{~ns}$ & 0.28 & $0.04^{*}$ & $0.21 \mathrm{~ns}$ & $0.00^{* *}$ & $0.48 \mathrm{~ns}$ \\
\hline
\end{tabular}

BIN: bored internode by $E$. saccharina; NMS: number of millable stalks $/$ ha; $\mathrm{SE}_{\text {mean }}=\mathrm{SD}_{\text {mean }} / \sqrt{ } \mathrm{n}$

(97 188 t sugar).

\section{DISCUSSION}

\section{Nitrogen rates and timing}

$\mathrm{N}$-rates in this experiment were applied at once in line of findings obtained under Ferké farming conditions where two applications of $\mathrm{N}$-fertilizer at planting and tillering stage did not significantly influence cane and sugar yields compared with a single application (Péné et al., 2018; Péné and Koulibaly, 2011). In contrast, in other sugarcane producing areas like under mineral soils of southern Florida (FL, USA) under very low organic matter content, nitrogen must be supplied in split fertilizer applications (Mabry McCray et al., 2017). Moreover, the absence of significant differences between $\mathrm{N}$ rates in plant cane as opposed to first ratoon crop is explained by mobilization of enough soil nitrogen resulting from mineralization of organic matter due to soil tillage. Therefore, $\mathrm{N}$ was not a yield limiting factor in plant cane compared with first ratoon crop. This is in line with findings reported by Mabry McCray et al., 2017; VieiraMegda et al., 2015; Cao et al., 2018. Yield response curves to nitrogen obtained in this study for both cropping cycles investigated were relatively flat (Figure 2) which shows a very low $\mathrm{N}$ recovery or $\mathrm{N}$ use efficiency. Therefore, $\mathrm{N}$ application rates higher than 100 to 110 $\mathrm{kg} / \mathrm{ha}$ in Ferké sugarcane farming conditions it used to be recommended before on plantations of good potential were subject to environmental concerns due to nitrogen leaching in soil profiles as well as pest damage to crop. This corroborates the fact that the recommended $\mathrm{N}$ application rate is dependent on many factors, including soil type, crop age, plant and soil properties, climate, length of growing cycle, and length of growing season (Wiedenfeld, 2000; Wood et al., 1996). Synthetic N fertilizer has facilitated very significant yield increases in modern agriculture but only 30 to $50 \%$ of the annually applied 109 million tons of $\mathrm{N}$-fertilizer are used by crops (Robinson et al., 2011; Tilman et al., 2002; FAOSTAT Website). The resulting pollution of land, water and atmosphere with reactive $\mathrm{N}$ is a pressing global problem, and it is imperative to improve the efficiency of $\mathrm{N}$ fertilizer supplied to crop systems (Erisman et al., 2008). Tropical and subtropical crop systems present a particular challenge because extreme rainfall events and weathered soils promote rapid $\mathrm{N}$ loss. Sugarcane is a food crop of industrial scale grown on 24 million ha in the tropics and subtropics, producing 1.6 billion tons of biomass annually and providing the largest contribution of any crop to global biofuel production (Somerville et al., 2010). While sugarcane is ranked the most suitable biofuel feedstock from energy conservation and environmental impact perspectives (Miller, 2010), its sustainability is arguable. Nitrogen fertilizer recovery by sugarcane is comparatively low and ranges from 20 to $40 \%$ (Franco et al., 2010) with up to $65 \%$ of applied $\mathrm{N}$-fertilizer lost from the sugarcanesoil system (Chapman et al., 1994). These losses occur 




Figure 3. Stem borer infestations (bored canes and internodes) of first ratoon crop in response to increasing $\mathrm{N}$-fertilizer rates In Ferké, Northern Ivory Coast.

via pathways that include nitrate leaching, ammonia volatilization, and gaseous emissions through microbial conservation of ammonium and nitrate (Vallis et al., 1996; Rasiah et al., 2003; Thorburn et al., 2005; Allen et al., 2010). Recent analysis of $\mathrm{N}$-fertilized sugarcane soils showed that emissions of nitrous oxide, a potent greenhouse gas, exceed current IPCC estimates severalfold (Allen et al., 2010). While the potential $\mathrm{N}_{2}$-fixing endophytes to contribute to the $\mathrm{N}$ balance has been reported in Brazilian sugarcane (Urquiaga et al., 1992), the ability for biological $\mathrm{N}$ fixation to supply an important proportion of crop $\mathrm{N}$-requirement has not been substantiated in other high-production systems (Biggs et al., 2002; Hoefsloot et al., 2005).

\section{Influence of fertilizer applications on stem borer damage}

A significant reduction in stem borer damage was observed in 2017-18 for both Ferké farmlands and particularly in Ferké $1(-1 \%)$ could be partly explained by lower rates of nitrogen fertilizer applied (25 to $30 \%$ reduction) in 2016-17 depending on crop cycle of plantations (plant cane or ratoon). This corroborates important differences in stem borer damage observed in 2016-17, due to nitrogen fertilizer rates, on same nursery varieties planted in both Ferké farmlands (Fig 6). High damage observed in 2017-18 on tolerant or resistant varieties such as R570, SP81-3250 and N21 over newly cleared plantations with richer soils in organic matter and nitrogen regarding four different sugarcane farmlands in Ivory Coast (Ferké 1, Ferké 2, Borotou and Zuénoula), tend to confirm the excessive nitrogen rate as the main cause. Evidence of the relationship between nitrogen and E. saccharina damage was shown in South Africa by Atkinson and Carnegie (1989). In Cuba, South America, findings on Diatraea saccharalis showed also that $\mathrm{N}$ fertilizer rates above $100 \mathrm{~kg} / \mathrm{ha}$ were responsible for a sudden increase of stem borer damage (Kvedaras et al., 2007). These findings showed also that damage level were higher when $\mathrm{N}$ application was done at early grand growth stage of sugarcane as internodes were tender for stem borer attacks. This corroborates findings related to two sugarcane farmlands close to Durban (South Africa), which showed that industrial plantations subjected to higher $\mathrm{N}$-fertilizer rate $(134 \mathrm{~kg} / \mathrm{ha})$ were more damaged compared to only $50 \mathrm{~kg} / \mathrm{ha}$ for village plantations more healthy (Goebel et al., 2005). A positive correlation between $\mathrm{N}$-fertilizer rates and the percentage of cane stalks damaged was made which suggested that above $125 \mathrm{~kg}$ of $\mathrm{N} / \mathrm{ha}$ stem borer attacks were intensified. According to Goebel et al. (2008), nitrogen is not only a yield factor in sugarcane but also a key element for the development of stem borer larva. This explains the propensity of the insect female adult to lay its legs in leaf axils of cane stalks with high $\mathrm{N}$ content in order to maintain its life cycle by determining better places for its larva feeding and fast development.

As reported by several authors, silicon application in sugarcane grown on tropical weathered soils which are therefore poor in this element like on Ferké farmlands, 
would enhance cane stalk resistance to stem borer damage levels (Meyer et al., 1998; Keeping and Meyer, 2002; Wang, 2005) cited by Goebel et al. (2008). It is estimated that the beneficial effect of silicon application on susceptible varieties to stem borer could prevent 20 to $30 \%$ of sugar yield losses due to E. saccharina, cane yield losses excluded (Goebel et al., 2008). This could explain improvement in the resistance of susceptible varieties to stem borer damage under water stress on rich soils in silicone by chemical changes in the concentration and structure of silicone within cane stalks. These changes could reinforce the barrier effect of stalk bark to the penetration of insect larva, although the hardness of cane tissues was not affected.

\section{Influence of sugarcane varieties cultivated}

Cane varieties known as susceptible to stem borer attacks in the agro-ecological context of Ferké are M1176/77, SP71-8210, SP75-184 and NCo376. They are characterized by sticking hold leaves on cane stems and stems with cracks which enhance the development of insect larva and their easy penetration into cane stalks. According to Goebel et al. (2008), selection of resistant or tolerant varieties remains so far as the most successful method to control stem borer. They reported that the development of tolerant or resistant varieties to Diatraea saccharalis such as NCo310, CP52-68 and L62-96 resulted in significant reduction of infestations and therefore that of insecticide treatments (Hensley et al., 1977). Other works carried out in South Africa and Reunion Island have identified cane varieties resistant or susceptible to $E$. saccharina and $C$. sacchariphagus (Goebel et al., 2008; Keeping, 2006). That is the case of R570 and R579 known as resistant and susceptible varieties, respectively (Goebel et al., 2000). Nevertheless, interactions between cane varieties and some farming conditions such as high $\mathrm{N}$ rates and water stress tend sometimes to reconsider the status of so called resistant or tolerant varieties. That was the case of R570 in Ivorian sugarcane growing areas as mentioned earlier. Similarly, certain varieties so called susceptible like R579 may escape heavy or moderate infestations as long as farming conditions remain optimum ( $\mathrm{N}$ fertilizer rate, soil water status) as it was observed during 2015-16 and 2017-18 cropping seasons in Ferké 2 sugarcane plantations.

\section{Towards an integrated stem borer management strategy}

Different studies on both main sugarcane stem borers showed their relative susceptibility to local agroecological conditions, including farming practices (Péné et al., 2018; Goebel et al., 2010; Parra et al., 2010; Do
Thi Khanh et al., 2012; Nikpay et al., 2014; Goebel et al., 2018). The regional workshop for west and central Africa on stem borer management held on late march 2018 in Ferké (Ivory Coast) allowed to sensitize main actors from height sugar companies on the relevance of implementing an integrated approach to effectively achieve that goal. It involves the use of resistant or tolerant varieties to stem borer attacks, a sound fertilizer application strategy, the plurality of landscapes required to increase faunistic and floristic biodiversity, farming practices preserving natural enemies of insect pests. It is the case of mechanized green harvesting of sugarcane with trash blanketing being practiced on both Ferké farmlands 10 years ago. Over the last four years, about $30 \%$ of Ferké sugarcane plantations, that is, 3600 ha are subjected to that practice. If agro-ecological control of pests as opposed to classical control cannot respond faster, it can assure a sustainable crop protection against stem borer while preserving the environment. In this regard, foliar applications of silicon fertilizer and the installation of light traps against stem borer at different critical sites within sugarcane plantations should mark the next cropping seasons in Ferké.

\section{CONCLUSIONS}

Results showed that, in plant cane, yield performance, cane juice quality and stem borer infestations were not significantly influenced by fertilizer treatments indicating that nitrogen was not a limiting factor in the soil profile to crop growth and development probably due to the decay of organic matter as a result of soil tillage. In contrast, in first ratoon, cane yields and stem borer infestations in terms of bored cane and bored internode percentage were significantly influenced by $\mathrm{N}$-fertilizer treatments with an optimum rate of 100 to $110 \mathrm{~kg} \mathrm{~N} / \mathrm{ha}$. Cane yield increase resulting from additional $\mathrm{N}$-fertilizer applications to that optimum rate was very little compared to the return cost of fertilizer with higher levels of stem borer infestations (> 8\% BIN). Many agronomic factors like cane varieties, nitrogen and silicone fertilizer applications are key elements in agro-ecological management of $E$. saccharina populations. Farming practices such as mechanized green harvesting and cultivation of service plants in the vicinity of cane plantations are suggested to enhance biodiversity, soil fertility and therefore soil fauna in creating favorable conditions for controlling stem borer damage. These actions may need to be associated with a tight monitoring of stem borer population dynamics with light traps within sugarcane plantations targeted by this pest.

\section{REFERENCES}

Allen D, Kingston G, Rennenberg H, Dalal RC, Schmidt S (2010). Effect of nitrogen fertilizer management and waterlogging on nitrous 
oxide emission from subtropical soils. Agric. Ecosyst. Environ. 136:209-17.

Atkinson PR, Carnegie AJM (1989). Population dynamics of the sugarcane borer, Eldana saccharina W (Lepidoptera: Pyralidae). Bull. Entomol. Res., 97:489-506.

Biggs I, Stewart G, Wilson J, Critchley C (2002). Nitrogen-15 natural abundance studies in Australian commercial sugarcane. Plant Soil 238:21-30.

Cao P, Lu C, Yu Z (2018). Historical N-fertilizer use in agricultural ecosystems of the contiguous United States during 1850-2015: application rate, timing, and fertilizer types. Earth Syst. Sci. Data 10:969-84.

Chapman I, Hayson MBC, Saffigna PG (1994). The recovery of $15 \mathrm{~N}$ from labelled urea fertilizer in crop components of sugarcane and in soil profiles. Aust. J. Agric. Res. 45:1577-85.

Conlong DE (1994). A review and perspectives for the biological control of the African sugarcane stalk borer Eldana saccharina W (Lepidoptera: Pyralidae). Agric. Ecosyst. Environ. 48:9-17.

Dick $J$ (1945). Some data on the biology of the sugarcane borer (Eldana saccharina W). Proc. South Afr. Sugar Cane Technol. Assoc. 19:75-79.

Do Thi Khanh H, Gobel FR, Marquier M, Fandon J, Roux E, Clain C, Colomel E, Tabone E (2012). Contrôle biologique du foreur ponctué de la canne à sucre à la Réunion par lâchers inondatifs de trichogrammes: Étapes franchies pour un développement à grande échelle. Actes Congrès sucrier AFCAS-ARTAS 2012, La Réunion. pp. 1-11.

Erisman J, Sutton MA, Galloway J, Klimont Z, Winiwarter W (2008). How a century of ammonia synthesis changed the world. Nat. Geosci. 1: 636-39.

FAO (2015). World reference base for soil resources 2014: International soil classification system for naming soils and creating legends for soil maps. Rome, FAO, p. 203.

FAOSTAT Website. Available: http://faostat.fao.org. Accessed 2011, Jan. 24.

Franco H, Otto R, Faroni C, Vitti A, Oliveira E (2010). Nitrogen in sugarcane derived from fertilizer under Brazilian field conditions. Fields Crops Res. 121 (1):29-41.

Goebel FR, Beuzelin JM, Way MJ (2018). Progress in understanding and managing insect pests affecting sugarcane. In: Achieving sustainable cultivation of sugarcane Vol. 2: Breeding, pests and diseases. Ph Rott eds: pp. 363-394.

Goebel FR, Fernandezz E, Begue JM, Tbère R, Aleuzet C (2000). Predation and varietal resistance as important components of integrated protection of the sugarcane stem borer Chilo sacchariphagus Bojer in Réunion Island. In: Sugarcane Pest Management in the new millennium. ISSCT Entomology Workshop: pp. 51-59.

Goebel FR, Nikpay, A (2017). Integrated pest management in sugarcane cropping systems. In: Integrated pest management in tropical regions. Rapisarda, C., Massimino-Cocuzza, G.E. (Eds.). CAB International: pp. 113-133.

Goebel FR, Tabone E, Do Thi Khanh H, Roux E, Marquier M, Frandon J (2010). Biocontrol of Chilo sacchariphagus (Lepidoptera: Crambidae) a key pest of sugarcane: lessons from the past and future prospects. Sugarc. Intern. 28:128-32.

Goebel FR, Way M, Conlong D (2008). La gestion des foreurs de la canne à sucre, l'environnement et les pratiques culturales: synthèse des résultats et perspectives. In: Actes Congrès sucrier ARTASAFCAS 2008, La Guadeloupe: pp. 1-12.

Goebel FR, Way MJ, Gossard B (2005). The status of Eldana saccharina (Lepidoptera: Pyralidaea) in South African sugar industry based on regular survey data. Proc. South Afr. Sugar Cane Technol. Assoc. 79:337-346.

Hensley SD, Fanguy HP, Giamalva MJ (1977). The role of varietal resistance in control of the sugarcane borer Diatraea saccharilis (F.) in Louisiana. In: Intern. Soc. Sug. Technol. 16:517-22.

Hoarau M (1970). La canne à sucre. Le technician d'agriculture tropicale. Maisonneuve et Larose (eds). p. 165.

Hoefsloot G, Termorshuizen AJ, Watt DA, Cramer MD (2005). Biological nitrogen fixation is a major contributor to the nitrogen demand of a commercially grown South African sugarcane cultivar.
Plant Soil 277:85-96.

Hugot E (1999). Sucrerie de canne. Paris, Collection Tech \& Doc, Lavoisier (eds). p. 1018.

Keeping MG (2006). Screening of South African sugarcane cultivars for resistance to the stalk borer, Eldana saccharina W (Lepidoptera: Pyralidae). Afr. Entomol. 14:277-288.

Keeping MG, Meyer JH (2002). Calcium silicate enhances resistance of sugarcane to the African stalk borer Eldana saccharina W (Lepidoptera: Pyralidae). Agricul. Forest Entomol. 4:256-74.

Konan EA, Péné CB, Dick E (2017a). Main factors determining the yield of sugarcane plantations on Ferralsols in Ferké 2 sugar complex, Northern Ivory Coast. J. Emerg. Trends Engineer. Appl. Sci. JETEAS 8(6):244-256.

Konan EA, Péné CB, Dick E (2017b). Caractérisation agro-climatique du périmètre sucrier de Ferké 2 au Nord de la Côte d'Ivoire. J Appl. Biosci. 116: 11532-11545.

Kouamé KD, Péné CB, M Zouzou (2010). Évaluation de la résistance variétale de la canne à sucre au foreur de tiges tropical Africain (Eldana saccharina W) en Côte d'Ivoire. J Appl. Biosci. 26: 16141622.

Kvedaras OI, Keeping MG, Goebel FR, Byrne M (2007). Water stress augments silicon-mediated resistance of susceptible sugarcane cultivars synergy in resistance of sugarcane cultivars to stalk borer, Eldana saccharina Walker (Lepidoptera: Pyralidaea). Bull. Entomol. Res. 97:175-183.

Leslie GW (2009). Estimating the economic injury level and the economic threshold for the use of a-cypermethrin against the sugarcane borer, Eldana saccharina W (Lepidoptera: Pyralidae). Ann. Appl. Biol. 155:349-359.

Lopez E, Fernandez C, Lopez O (1983). Effect of nitrogen fertilisation on Diataea saccharalis (Fabr.) incidence on sugarcane. Proc. Intern. Soc. Sugarc. Technol. 18:910-914.

Mabry McCray J, Ji S, Ulloa M (2017). Influence of compost/sludge application on sugarcane yield and nitrogen requirement on a sand soil. J. Plant Nutr. 40(15):2156-67.

Mazodze R, Conlong DE (2003). Eldana saccharnica W (Lepidoptera: Pyralidae) in sugarcane (Saccharum hybrids), sedge (Cyperus digitatus) and bulrush (Typha latifolia) in South-eastern Zimbabwe. Proc. South Afr. Sugar Cane Technol. Assoc. 77:256-274.

McFarlane SA, Govender P, Rutherford RS (2009). Interactions between Fusarium species from sugarcane and the stalk borer, Eldana saccharina W (Lepidoptera: Pyralidae). Ann. Appl. Biol. 155:349-359.

Meyer JH, Harding R, Rampersad AL, Wood RA (1998). Monitoring long term soil fertility trends in the South African sugar industry using the FAS analytical database. Proc. South Afr. Sugar Cane Technol. Assoc. 72:61-68.

Miller SA (2010). Minimizing land use and nitrogen intensity of bioenergy. Environ. Sci. Technol. 44:3932-39.

Nikpay A, Kord H, Goebel FR, Sharafizadeh P (2014). Assessment of natural parasitism of sugarcane moth borer Sesamia spp by Telenomus busseolae in five commercial cultivars. Sugar Tech. 16(3):325-8.

Nikpay A, Soleyman-Nejadian E, Goldasteh S, Farazmand H (2015). Response of sugarcane and sugarcane stalk borers Sesamia spp. (Lepidoptera: Noctuidae) to calcium silicate fertilization. Neotrop. Entomol. 44:498-503.

Parra JRP, Botelho PSM, Pinto AS (2010). Biological control of pests as a key component for sustainable sugarcane production. In: L.A.B Cortez (eds), Sugarcane Bioethanol: Rand for Productivity and Sustainability, SP, Brazil pp. 441-50.

Paxton RH (1982). Eldana borer (E. Saccharina): the results of surveys. Proc. South Afr. Sugar Cane Technol. Assoc. 56:99-103.

Péné CB, Boua BM, Coulibaly-Ouattara Y (2019). Nouvelles variétés de canne à sucre (Saccharum officinarum $L$ ) adaptées aux conditions pluviales dans les périmètres sucriers de Ferké au Nord Côte d'Ivoire. [New sugarcane (Saccharum officinarum L.) varieties adapted to rainfed conditions in Ferké sugar plantations, Northern Ivory Coast] J. Appl. Biosci. 134:13702-13710.

Péné CB, Kouamé KD, Dove H, Boua BM (2016). Incidence des infestations du foreur de tiges Eldana saccharina W (Lepidoptera: Pyralidae) en culture irriguée de canne à sucre selon la variété et la 
période de récolte en Côte d'Ivoire. J Appl. Biosci. 102:9687-9698.

Péné CB, Koulibaly, SG (2011). Sugarcane yield variations in northern and central Ivory Coast as influenced by soil water balance over two critical growth stages. J. Agric. Sci. Technol. 5(2):220-25.

Péné CB, Ouattara HM, Koulibaly GS (2012). Late season sugarcane performance as affected by soil water regime at the yield formation stage on commercial farms in northern Ivory Coast. J. Life Sci. 6(6):644-651.

Péné, CB, Boua BM, Coulibaly-Ouattara Y, Goebel FR (2018). Stem borer (Eldana saccharina W.) infestation outbreak in sugarcane plantations of Northern Ivory Coast: Management strategies under implementation. Am. J. Biosci. Bioengin. 6(4):27-35.

Polaszek A (1998). African Cereal Stem Borers: Economic Importance, Taxonomy, Natural Enemies and Control. p. 530. Wallingford, UK, CAB International (ISBN: 0851991750).

Rasiah V, Armour J, Menzies N, Heiner D, Donn M (2003). Nitrate retention under sugarcane in wet tropical Queensland deep soil profiles. Austr. J. Soil Res. 41:1145-61.

Robinson N, Brackin R, Vinal K, Soper F, Holst J, Gamage H, Paungfoo-Lonhienne C, Rennenberg $\mathrm{H}$, Laksmanan P, Schmidt $\mathbf{S}$ (2011). Nitrate paradigm does not hold up for sugarcane. Plos One 6(4):1-9. e19045.

Somerville C, Youngs H, Taylor C, Davis SC, Long SP (2010). Feedstocks for lignocellulosic biofuels. Sci. 329:790-92.

Thorburn PJ, Meier EA, Probert ME (2005). Modelling nitrogen dynamics in sugarcane systems: Recent advances and applications. Field Crops Res. 92:337-51.

Tilman D, Gassman KG, Matson PA, Naylor R, Polasky S (2002). Agricultural sustainability and intensive production practices. Nature 418:671-677.

Urquiaga S, Cruz K, Boddey R (1992). Contribution of nitrogen fixation to sugarcane: nitrogen-15 and nitrogen balance estimates. Soil Sci. Soc. Am. J. ISSN: 0361-5995.
USDA (1999). Soil taxonomy: A basic system of soil classification for making and interpreting soil surveys. $2^{\text {nd }}$ Edition. USDA, p. 861.

Vallis I, Catchpoole VR, Hughes RM, Myers RJK, Ridge DR (1996). Recovery in plants and soils of $15 \mathrm{~N}$ applied in as subsurface bands to sugarcane. Austr. J. Agric. Res. 47:355-70.

Vieira-Megda MX, Mariano E, Leite JM, Franco HCJ, Vitti AC, Megda MM, Khan SA, Mulvaney RL, Trivelin PCO (2015). Contribution of $\mathrm{N}$-fertilizer to total $\mathrm{N}$ extracted by sugarcane under Brazilian field conditions. Nutr. Cycling Agroecosyst. 101(2):241-257.

Wang MQ (2005). Effect of complete silicon fertilizer on rice yield. Acta Agric. Shanghai 21:71-73.

Way MJ, Goebel FR, Gillespie W (2003). Surveying Eldana saccharina (Lepidoptera: Pyralidaea) in a small-scale grower sector of the South African sugarcane industry. Proc. South Afr. Sugar cane Technol. Assoc. 77:275-277.

Wiedenfeld RP (2000). Water stress during different sugarcane growth periods on yield and response to $\mathrm{N}$-fertilization. Agric. Water Manage. 43:173-82.

Wood AW, Muchow RC, Robertson MJ (1996). Growth of sugarcane under high input conditions in tropical Australia. III. Accumulation, partitioning and use of nitrogen. Field Crops Res. 48:223-33. 